\title{
THE EFFECTS OF STRUCTURED C RITICISM UPON THE \\ PERCEPTUAL DIFFERENTIATION AND STUDIO COMPOSITIONAL SKILLS DISPLAYED BY COLLEGE ELEMENTARY EDUCATION STUDENTS
}

\section{Dora Janov}

\section{Introduction}

This study attempts to investigate the possibility of obtaining an increase in the perceptual differentiation skills of elementary education students with limited art backgrounds and experience. The instructional strategy under consideration compares various degrees of student involvement with a structured criticism model. A description of the relationships among the level of perceptual differentiation, the degree of involvement in structured critique sessions, and the utilization of compositional strategies in students' drawings is intended to provide information regarding the question of critical periods in perceptual development as posed by Eisner (1980, p. 598). This information should prove to be helpful in the development of curriculum for preparing elementary classroom teachers.

\section{Background of the Problem}

Two of the central goals of the field of art education are to develop the students' ability to experience the visual world aesthetically and to develop their ability to form visual images in some material that expresses their personal experience (Eisner, 1973). Encouraging students to participate in the production of art work, and assisting them to respond to art work are educational endeavors which are inherently related to the improvement of perceptual skills. Evidence has been accumulated to indicate that the enhancement of perceptual differentiation in children is achievable through various instructional strategies which employ some aspect of perceptual training (Dunn, 1978; Dorethy, 1972; Salome, 1965; Salome and Reeves, 1972).

Research also indicates that involvement in art production does not result in increased perceptual awareness, unless instruction has been designed to specifically cause students to attend to visual cues in the environment (Salome, 1965). It has been demonstrated that increased perceptual differeniation is an attainable goal and that increased perceptual differentiation results in an increase in student attention to perceptual cues in art production (Salome, 1965; Dorethy, 1972; Dunn, 1978). Elementary children are able to profit from instruction in perceptual awareness, but leadership and instructional strategy must be provided in order to encourage optimum development of perceptual differentiation. A recent report done for the J. Paul Getty Trust states that instruction in the visual arts contributes to the sharpening of perceptive and analytical skills among students. But the fact that the nation's public schools have generally neglected art education is also emphasized ( $W$ vilson, 1985). The majority of elementary children are not afforded the opportunity of experiencing this guidance toward increased awareness because instructional staffing in art education at the elementary 
level is not given priority, in fact, is regarded as unnecessary when budget cuts are demanded (Hatfield, 1973; Chapman, 1982).

Only a small percentage of school districts provide certified art teachers or a formal art program at the elementary level (Miller, 1983), and the majority of elementary school art instruction is carried on by classroom teachers (Chapman, 1971; 1982, p. 67). Elementary teachers who have limited preparation in art education are able to introduce art activities in the classroom, but are not able to provide guidance in the process of perceptual development or guided criticism for their elementary students (Eisner, 1980).

The cycle perpetuates itself. Elementary students receive minimal art instruction, lack differentiated visual perceptual skills, have limited a wareness of the relationship between perception and production in art, and have no idea that a void exists. Some of these students will pursue educational goals and eventually prepare themselves to be elementary teachers, given the responsibility for providing a modicum of art instruction in the classroom, in the absence of professional art educators at that level. Hence the void is perpetuated, not by malice or intent, but a lack of awareness.

\section{Significance of the Problem}

Information is needed which will provide a basis for developing techniques aimed at increasing the perceptual skills and awareness of preparing elementary education students. If the utilization of an instructional strategy involving art criticism can be demonstrated to have potential for increasing perceptual skills of college elementary education students, the possibility for intervention exists.

Questions regarding the use of pedagogical art criticism, specifically the linguistic and structural aspects of the criticism process, as an instructional strategy for increasing perceptual differentiation remain uninvestigated. Evidence concerning this topic will assist in the development of more efficient and productive art education curriculum models for preparing elementary teachers.

\section{Statement of the Problem}

This study will center on the utilization of a structured criticism model as a strategy for increasing the visual perceptual skills of differentiation in college elementary education majors. The degree of student involvement in the criticism format and the focus of attention during critique sessions are the variables under investigation. A description of the relationships which occur among perceptual differentiation, the degree of student involvement in structured criticism activities, and the students' demonstration of compositional strategies based upon the criticism matrix may provide information which will be beneficial in developing curriculum for preparing elementary classroom teachers.

Visual perception differentiation and pedagogical art criticism as an aspect 
of art instruction are central issues in this study. Much emphasis has been placed upon the development of the critical aspect of art learning as an integral component of the process of art education (Eisner, 1972; Chapman, 1978; Mittler, 1980). Art criticism has been viewed as a process for expanding art preferences, and for modifying attitudes about art works (Feldman, 1967; Gilliat, 1979; Mittler, 1972). Dewey (1933) suggests that the end of criticism is the re-education of the perception of a work of art. Feldman (1967) states that criticism should be an orderly undertaking which strives to raise the quality of perception and increases aesthetic understanding. In his delineation of the types of criticism, specific reference is made to pedagogical criticism, which is inteded to advance the artistic and aesthetic maturity of students. It does not so much seek to render authoritative judgments upon work by students as it does enable students eventually to make such judgments for themselves (1967, p. 453).

Feldman's art criticism model consists of four stages:

Description,

Formal Analysis,

Interpretation, and

Valuation or Judgment.

These are fundamentally different operations and are arranged sequentially from specific to general, and operationally from a simple description of the obvious elements of the work of art to the difficult task of judging its artistic and aesthetic merit.

This criticism approach is recommended by Smith (1970) and utilized in part by Mittler (1976) in the development of a matrix which illustrates the fundamental design relationships that are created by the interaction of the elements and principles of art. The purpose of the matrix is to offer these design relationships as a range of alternatives from which students may deliberately choose when producing their own art work (Mittler, 1976).

The critique format generates an organizational mechanism which will provide opportunity for the student to attend visually to the task and utilize the perceptual information derived from an encounter with the stimulus. Any organization of information that reduces the aggregate complexity of material by embedding it into a cognitive structure which a person has constructed will make the material more accessible for retrieval. The key to retrieval is organization (Bruner, 1970, p. 101). Perceptual differentiation occurs as the viewer continues to push for structural analysis. The development of competencies in the critical aspects of art may increase the number of conceptual tools a student is able to use in the productive aspect of art. (Eisner, 1966, p. 50).

The theoretical tenents for the perceptual aspects of this study lie in the area of psychology. Gibson and Gibson developed a differentiation theory of visual perception in 1955 which has potential for application in art 
education in that it allows for instruction as an important component of increased perceptual differentiation. Gibson (1969) defines perception as "the process by which we obtain firsthand information about the world around us" (p. 3). Perception is active and adaptive, and perceptual learning is self-regulated and progresses toward the reduction of uncertainty in processing stimulus information. The cybernetic model developed by Gibson (1969) demonstrates the progressive interaction between perception and cognitive development.

Gibson's differentiation theory is the psychological base for the approach to perception in this study. The aspects of the study which are directed toward the development of instructional strategies are rooted in Bruner's approach to perception as a problem-solving activity (1957). These two theories are remarkably parallel and provide a basis for the pedagogical structure which employs the criticism model as an instructional strategy directed toward enhancement of the visual perceptual skills of elementary education students.

\section{Design of the Study}

Briefly, the organizational design for this study consists of four intact classes of elementary art education students at Ball State University. One class serves as a control group. The other three classes are instructed by the investigator, and are experimental groups. An adaptation of Mittler's analysis matrix is incorporated within the course content. The criticism involvement and focus vary for these three groups.

In Group I, students generate the description and analysis stages of the matrix and focus upon art products created by individuals within the group.

In Group II, discussion of the description and analysis stages of the matrix is presented by the instructor with focus upon the art products created by individuals within the group.

In Group III, discussion of the description and analysis stages of the matrix is generated by the instructor asking questions to stimulate student involvement. The focus is upon recognized works of art, viewed by slide presentation.

Two measures will be used for this study. The Group Embedded Figures Test (GEFT) developed by Witkin (1971) and associates will be administered as a pre- and post-test to all groups.

The second measure, the Student Composition Rating Scale (SCRS) is developed specifically for this study. It is an adaptation of the Dunn Photographic Rating Scale. It will also be administered as a pre- and post-test to all groups.

\section{REFERENCES}

Bruner, J. S. (1957). Going beyond the information given. Contemporary approaches to cognition. Cambridge, Mass: Harvard University Press. 
Bruner, J. S. (1970). The act of discovery. Concepts in art and education. Pappas, G., ed. New York: Macmillan Co.

Chapman, L. (1971). Recent trends and problems in art education. Encyclopedia of education. New York: Macmillan Co.

Chapman, L. (1978). Approaches to art in education. New York: Harcourt Brace Jovanovich, Inc.

Chapman, L. (1982). Instant art instant culture. New York: Teachers College Press.

Dewey, J. (1933). How we think. Boston: D. D. Heath, Co.

Dorethy, R. E. (1972). Motion parallax as a factor in the differential spatial abilities of young children. Studies in art education, 14, 15-27.

Dunn, P. C. (1978). The implementation of photographic visual problem solving strategies to enhance levels of visual perception in elementary school art students. Unpublished dissertation.

Eisner, E. W. (1966). The development of information and attitude toward art at the secondary and college levels. Studies in art education, 8, (1).

Eisner, E. W. (1972). Educating artistic vision. New York: Macmillan Co.

Eisner, E. W. (1973). Research on teaching the visual arts. Second handbook of research on teaching. Travers, R., ed. Chicago: Rand McNally and Co.

Eisner, E. W. (1980). What we don't know about the teaching of art. Phi Delta Kappan, 61, 598-599.

Feldman, E. B. (1967). Art as image and idea. Englewood Cliffs, N J: Prentice Hall, Inc.

Gibson, E. J. (1969). Principles of perceptual learning and development. Englewood Cliffs, NJ: Prentice Hall, Inc.

Gilliat, M. T. (1979). The effects of habituation, the Feldman-Mittler methodology, and studio activities on expanding art preferences of elementary students. Studies in art education, 21, 43-49.

Hatfield, T. (1978). Arts, politics, and change in the schools. Arts education and back to basics. Dobbs, S., ed. NAEA.

Miller, P. K. (1983). Art teacher training must change! Art education, 36, (5).

Mittler, G. (1972). Efforts to secure congruent and incongruent modifications of attitude toward works of art. Studies in art education, 13, 58-70.

Mittler, G. (1976). Perceptual thoroughness as a prelude to discriminate decision-making in art. Viewpoints, 52, 15-29.

Mittler, G. (1980. Learning to look/looking to learn. Art education, 33, 17-21.

Salome, R. A. (1965). The effects of perceptual training upon the two-dimensional drawings of children. Studies in art education, 7, 18-33.

Salome, R. A. and Reeves, D. (1972). Two pilot investigations of perceptual training of four- and five-year-old kindergarten children. Studies in art education, 13, 3-10.

Smith, R. A. (1970). Aesthetic criticism: the method of aesthetic education. Concepts in art education. Pappas, G., ed. New York: Macmillan Co.

Wilson, W. (1985). Art education should focus more on history, criticism, says report. The Indianapolis Star, April 14, $11 \mathrm{E}$.

Witkin, H. A., Oltman, P. K., Raskin, D. and Karp, S.A. (1971). A manual for the embedded figures test. Palo Alto, Calif: Consulting Psychologists Press, Inc. 